Nitin Seam

Anthony F. Suffredini

\section{Steroids are part of rescue therapy in ARDS patients with refractory hypoxemia: we are not sure}

Received: 14 November 2015

Accepted: 19 November 2015

Published online: 29 January 2016

(C) Springer-Verlag Berlin Heidelberg and ESICM 2016

For contrasting viewpoints, please go to

doi:10.1007/s00134-015-4162-x and

doi:10.1007/s00134-015-XXXX-X.

N. Seam · A. F. Suffredini $(\bowtie)$

Critical Care Medicine Department, Clinical Center,

National Institutes of Health, Building 10, Room 2C145,

10 Center Drive, Bethesda, MD 20892-1662, USA

e-mail: asuffredini@cc.nih.gov

Many clinicians have ambivalence regarding the use of steroids in critical illness. In a survey of corticosteroid use in the ICU, more than half would use steroids in vasopressor-refractory septic shock while the majority of respondents almost never use corticosteroids for ARDS [1]. Considering the nature of the injury, the high mortality and the underlying pathogenesis of ARDS, this is somewhat surprising. Patients with ARDS with higher levels of lung and systemic inflammation have worse clinical outcome [2, 3]. Because of its inflammatory basis, corticosteroids have long been considered a potential therapy for ARDS.

In a recent article in Intensive Care Medicine, Meduri et al. [4] describe an intention-to-treat analysis of individual patient data (IPD) from four randomized trials of patients with ARDS treated with methylprednisolone or placebo either early (within $72 \mathrm{~h}$ of onset) or late (after 5-7 days) after the onset of respiratory failure. They then performed a trial-level meta-analysis incorporating the IPD analysis with data from four randomized trials in which patients received 7 days of hydrocortisone or placebo for early ARDS. They found decreased time to unassisted breathing with methylprednisolone as well as a reduction in hospital mortality in their meta-analysis.
While their analysis is consistent with a potential benefit of prolonged corticosteroid therapy to improve outcomes in ARDS, the effects of corticosteroid dose on these variables is complicated by the different doses and duration of the corticosteroids used in the trials (Table 1).

Denoting steroids as rescue therapy assumes that usual care (i.e., reversing the underlying cause, limiting injury from mechanical ventilation and treating nosocomial infections), should be sufficient to decrease pulmonary inflammation and enhance survival. However, if these measures fail, rescue therapy with corticosteroids might be initiated to halt the decline in lung function and allow for recovery. If the mechanisms leading to organ injury and gas exchange abnormalities have some commonality, should steroids be considered as primary adjunctive therapy rather than rescue therapy?

The consensus definition of ARDS was developed as an epidemiologic tool and to facilitate the identification of consistent patient characteristics for clinical trials. However, it has limited fidelity to identify patients with lung injury who will benefit from anti-inflammatory therapy. The definition includes an amalgam of direct (i.e. pneumonia, aspiration, inhalational injury, contusion, vasculitis, drowning) and indirect (i.e. non-pulmonary sepsis, trauma, pancreatitis, severe burns, non-cardiogenic shock, drug overdose, transfusion-associated lung injury) injuries to the lung [5]. Are the trials that assess the effects of steroids studying the same types of patients or are the underlying processes too diverse to be summarized as a single clinical entity? Attempts to address the effects of steroids on ARDS due to different etiologies has had only limited success because of the varying mix of patients included in current reports [6].

To add to the complexity of identifying patients who will benefit from steroid therapy, one might assume that the clinical definition of a syndrome that shares common mechanisms of injury would have consistent histologic manifestations with the hallmark finding of diffuse 
Table 1 Dose and duration of methylprednisolone or hydrocortisone given to patients with ARDS

\begin{tabular}{|c|c|c|c|c|c|}
\hline $\begin{array}{l}\text { Studies cited } \\
\text { in Meduri et al. [4] }\end{array}$ & $\begin{array}{l}\text { Total number } \\
\text { of patients } \\
\text { treated with } \\
\text { placebo }\end{array}$ & $\begin{array}{l}\text { Total number of } \\
\text { patients } \\
\text { treated with } \\
\text { methylprednisolone }\end{array}$ & $\begin{array}{l}\text { Total dose }(\mathrm{mg}) \\
\text { of corticosteroid } \\
\text { days } 1-7 \\
\text { methylprednisone }^{\mathrm{a}}\end{array}$ & $\begin{array}{l}\text { Total hydrocortisone } \\
\text { equivalents }(\mathrm{mg}) \\
\text { days } 1-7^{\mathrm{b}}\end{array}$ & $\begin{array}{l}\text { Maximum duration } \\
\text { of steroid therapy } \\
\text { (days) }\end{array}$ \\
\hline Meduri et al. [16] & 8 & 14 & 1120 & 5600 & 31 \\
\hline Steinberg et al. [17] & 92 & 85 & 1120 & 5600 & 25 \\
\hline Meduri et al. [18] & 28 & 63 & 560 & 2800 & 28 \\
\hline Rezk et al. [19] & 9 & 18 & 560 & 2800 & 28 \\
\hline Total & 137 & 180 & & & \\
\hline $\begin{array}{l}\text { Studies cited in } \\
\text { Meduri et al. [4] }\end{array}$ & $\begin{array}{l}\text { Total number } \\
\text { of patients } \\
\text { treated with } \\
\text { placebo }\end{array}$ & $\begin{array}{l}\text { Total number } \\
\text { of patients } \\
\text { treated with } \\
\text { hydrocortisone }\end{array}$ & $\begin{array}{l}\text { Total dose (mg) } \\
\text { of corticosteroid } \\
\text { days } 1-7 \\
\text { hydrocortisone }\end{array}$ & $\begin{array}{l}\text { Total hydrocortisone } \\
\text { equivalents } \\
(\mathrm{mg}) \text { days } 1-7^{\mathrm{b}}\end{array}$ & $\begin{array}{l}\text { Maximum duration } \\
\text { of steroid } \\
\text { therapy (days) }\end{array}$ \\
\hline Confaloneri et al. [20] & 19 & 15 & 1880 & 1880 & 7 \\
\hline Annane et al. [21] & 66 & 66 & 1400 & 1400 & 7 \\
\hline Sabry et al. [22] & 34 & 26 & 2100 & 2100 & 7 \\
\hline Liu et al. [23] & 14 & 12 & 2100 & 2100 & 7 \\
\hline Total & 133 & 119 & & & \\
\hline
\end{tabular}

Patient numbers derived from Fig. 3 in [4]

Intravenous dosing strategy for methylprednisolone studies:

Meduri et al. [16] - Loading dose $2 \mathrm{mg} / \mathrm{kg}$ followed by $2 \mathrm{mg} / \mathrm{kg} /$ day from days $1-4$, then $1 \mathrm{mg} / \mathrm{kg} /$ day days $15-21$, the $0.5 \mathrm{mg} / \mathrm{kg} / \mathrm{day}$ from day $22-28,0.25 \mathrm{mg} / \mathrm{kg} /$ day on days 29 and 30 , then $0.125 \mathrm{mg} / \mathrm{kg} /$ day on days 30 and 31

Steinberg et al. [17] — Loading dose $2 \mathrm{mg} / \mathrm{kg}$ followed by a dose of $0.5 \mathrm{mg} / \mathrm{kg}$ of predicted body weight every $6 \mathrm{~h}$ for 14 days, a dose of $0.5 \mathrm{mg} / \mathrm{kg}$ of predicted body weight every $12 \mathrm{~h}$ for 7 days, and then tapering of the dose. Study drug was tapered over a period of 4 days if 21 days of treatment had been completed and the patient was unable to breathe without assistance for a period of $48 \mathrm{~h}$

Meduri et al. [18] — Loading dose of $1 \mathrm{mg} / \mathrm{kg}$ was followed by an infusion of $1 \mathrm{mg} / \mathrm{kg} /$ day from day 1 to day $14,0.5 \mathrm{mg} / \mathrm{kg} / \mathrm{day}$ from day 15 to day $21,0.25 \mathrm{mg} / \mathrm{kg} / \mathrm{day}$ from day 22 to day 25 , and $0.125 \mathrm{mg} / \mathrm{kg} / \mathrm{day}$ from day 26 to day 28 . If the patient was extubated between days 1 and 14, the patient was advanced to day 15 of drug therapy and tapered according to schedule

Rezk et al. [19]—Load $1 \mathrm{mg} / \mathrm{kg}$, then days $0-14 ; 1 \mathrm{mg} / \mathrm{kg} /$ day, days $15-21 ; 0.5 \mathrm{mg} / \mathrm{kg} / \mathrm{day}$, days 22-25; 0.25 mg/kg/day, days 26-28; $0.125 \mathrm{mg} / \mathrm{kg} /$ day

Intravenous dosing strategy for hydrocortisone studies:

Confaloneri et al. [20]-200 $\mathrm{mg}$ bolus then $10 \mathrm{mg} / \mathrm{h}$ for 7 days

Annane et al. [21] $-50 \mathrm{mg}$ hydrocortisone every $6 \mathrm{~h}$ and $50 \mathrm{mcg}$ fludrocortisone for 7 days

Sabry et al. [22] $-12.5 \mathrm{mg} / \mathrm{h}$ hydrocortisone for 7 days

Liu et al. [23] - $100 \mathrm{mg}$ hydrocortisone, three times per day for 7 days

a Estimate for $70 \mathrm{~kg}$ (body weight) patient

b Equivalent dose of hydrocortisone $20 \mathrm{mg}$ equals $4 \mathrm{mg}$ methylprednisolone

alveolar damage. Yet, autopsy studies of patients meeting the Berlin criteria for ARDS show that less than half of these patients had these findings at the time of death [7]. Other clinical diagnosis where ARDS criteria were met but no diffuse alveolar damage was found included pulmonary infections, cancer infiltration, pulmonary embolism, acute pulmonary edema, pulmonary hemorrhage, interstitial pneumonia/fibrosis, and severe emphysema as well as the absence of any pulmonary lesions [7]. Thus, it should not be surprising that a uniform treatment strategy for patients meeting the consensus definition of ARDS has limitations and lacks sufficient accuracy to identify inflammatory lung processes amenable to modulation with steroids.

Corticosteroids have shown benefit in many infectious and noninfectious lung injuries that lead to ARDS. Patients with Pneumocystis pneumonia may develop ARDS and have evidence of diffuse alveolar damage, while 21-day treatment with tapering doses of corticosteroids reduces mortality reduction in adults with significant hypoxemia due to Pneumocystis [8]. Diffuse alveolar hemorrhage (DAH) may present clinically as ARDS. Corticosteroids remain the standard treatment for DAH with capillaritis or DAH related to stem cell transplant or idiopathic pulmonary hemosiderosis [9].

However, corticosteroids are not a panacea for all lung inflammation. In immunosuppressed patients, such as hematopoietic stem cell transplant recipients, the antiinflammatory effects of corticosteroids for treatment of ARDS are weighed against worsening co-existing infections (e.g., cytomegalovirus, adenovirus, fungal pneumonias) or increasing the risk of nosocomial infections. A lack of benefit is suggested from studies describing corticosteroid use in severe influenza pneumonia. Retrospective studies found an increase in mortality in critically ill patients with $\mathrm{H} 1 \mathrm{~N} 1$ influenza receiving corticosteroids compared to propensity matched controls $[10,11]$. However, these data are limited by their 
retrospective nature and the variability in the dose, timing and duration of antivirals as well as corticosteroids.

If steroids are considered only as rescue therapy, when should therapy be initiated and what would the clinical signs be to demonstrate failure of other treatments? Histologic data from autopsies suggest that exudative lesions predominate during the first week, and that by the third week fibroproliferative changes become dominant [12]. As lung histology is rarely available in early ARDS, blood biomarkers (e.g., type III procollagen) may provide the clinical signal to initiate anti-inflammatory therapy [13]. Analysis of trial data from the current study suggests that if corticosteroids are used to treat ARDS, treatment should be initiated prior to day 14 .

We believe the question of primary or rescue steroid therapy for ARDS needs to be reframed. Significant gaps remain in the randomized trial data. The dose and duration of corticosteroids providing benefit in ARDS differed by two- to fivefold and 1-4 weeks in duration, respectively. These data suggest that one treatment strategy may not fit all patients fulfilling the clinical criteria of ARDS. Many investigators on both sides of this debate agree that the current clinical definition is limited in identifying patients with lung injuries that may be responsive to corticosteroids $[14,15]$. Expanding the current physiologic definition of ARDS with disease-specific biomarkers may help focus the debate [14]. In the absence of a specific tissue diagnosis or real-time biomarker signatures reflecting the etiology and stage of lung injury, the uncertainty and reservations regarding steroid use in ARDS will persist.

\section{Compliance with ethical standards}

Funding Supported by the Intramural Program, Clinical Center, National Institutes of Health.

Disclosures Dr. Seam and Suffredini serve on the Executive Committee of the US Department of Veterans Affairs Cooperative Studies Program (CSP) \#574: Evaluate the Safety and Efficacy of Methylprednisolone in Hospitalized Veterans with Severe CommunityAcquired Pneumonia (NCT01283009).

\section{References}

1. Lamontagne F, Quiroz Martinez $\mathrm{H}$, Adhikari NK, Cook DJ, Koo KK, Lauzier F, Turgeon AF, Kho ME, Burns KE, Chant C, Fowler R, Douglas I, Poulin Y, Choong K, Ferguson ND, Meade MO (2013) Corticosteroid use in the intensive care unit: a survey of intensivists. Can J Anaesth 60:652-659

2. Meduri GU, Headley S, Kohler G, Stentz F, Tolley E, Umberger R, Leeper K (1995) Persistent elevation of inflammatory cytokines predicts a poor outcome in ARDS. Plasma IL-1 beta and IL-6 levels are consistent and efficient predictors of outcome over time. Chest 107:1062-1073

3. Meduri GU, Kohler G, Headley S, Tolley E, Stentz F, Postlethwaite A (1995) Inflammatory cytokines in the BAL of patients with ARDS. Persistent elevation over time predicts poor outcome. Chest 108:1303-1314

4. Meduri GU, Bridges L, Shih M-C, Marik PE, Siemieniuk RAC, Kocak M (2015) Prolonged glucocorticoid treatment is associated with improved ARDS outcomes: analysis of individual patients' data from four randomized trials and trial-level meta-analysis of the updated literature. Intensive Care Med. doi:10.1007/s00134-015-4095-4

5. Ranieri VM, Rubenfeld GD, Thompson BT, Ferguson ND, Caldwell E, Fan E, Camporota L, Slutsky AS (2012) Acute respiratory distress syndrome: the Berlin definition. JAMA 307:2526-2533
6. Ruan SY, Lin HH, Huang CT, Kuo PH, Wu HD, Yu CJ (2014) Exploring the heterogeneity of effects of corticosteroids on acute respiratory distress syndrome: a systematic review and meta-analysis. Crit Care 18:R63

7. Thille AW, Esteban A, FernandezSegoviano P, Rodriguez JM, Aramburu JA, Penuelas O, Cortes-Puch I, CardinalFernandez P, Lorente JA, Frutos-Vivar F (2013) Comparison of the Berlin definition for acute respiratory distress syndrome with autopsy. Am J Respir Crit Care Med 187:761-767

8. Ewald H, Raatz H, Boscacci R, Furrer H, Bucher HC, Briel M (2015) Adjunctive corticosteroids for Pneumocystis jiroveci pneumonia in patients with HIV infection. Cochrane Database Syst Rev 4:CD006150

9. Lara AR, Schwarz MI (2010) Diffuse alveolar hemorrhage. Chest 137:1164-1171

10. Kim SH, Hong SB, Yun SC, Choi WI, Ahn JJ, Lee YJ, Lee HB, Lim CM, Koh Y, Korean Society of Critical Care Medicine HNC (2011) Corticosteroid treatment in critically ill patients with pandemic influenza A/H1N1 2009 infection: analytic strategy using propensity scores. Am J Respir Crit Care Med 183:1207-1214

11. Brun-Buisson C, Richard JC, Mercat A, Thiebaut AC, Brochard L (2011) Early corticosteroids in severe influenza A/H1N1 pneumonia and acute respiratory distress syndrome. Am J Respir Crit Care Med 183:1200-1206
12. Thille AW, Esteban A, FernandezSegoviano P, Rodriguez JM, Aramburu JA, Vargas-Errazuriz P, Martin-Pellicer A, Lorente JA, Frutos-Vivar F (2013) Chronology of histological lesions in acute respiratory distress syndrome with diffuse alveolar damage: a prospective cohort study of clinical autopsies. Lancet Respir Med $1: 395-401$

13. Forel JM, Guervilly C, Hraiech S, Voillet F, Thomas G, Somma C, Secq V, Farnarier C, Payan MJ, Donati SY, Perrin G, Trousse D, Dizier S, Chiche L, Baumstarck K, Roch A, Papazian L (2015) Type III procollagen is a reliable marker of ARDS-associated lung fibroproliferation. Intensive Care Med 41:1-11

14. Frohlich S, Murphy N, Boylan JF (2013) ARDS: progress unlikely with non-biological definition. Br J Anaesth 111:696-699

15. Thompson BT, Moss M (2013) A new definition for the acute respiratory distress syndrome. Semin Respir Crit Care Med 34:441-447

16. Meduri GU, Headley AS, Golden E, Carson SJ, Umberger RA, Kelso T, Tolley EA (1998) Effect of prolonged methylprednisolone therapy in unresolving acute respiratory distress syndrome: a randomized controlled trial. JAMA 280(2):159-165 
17. Steinberg KP, Hudson LD, Goodman RB, Hough CL, Lanken PN, Hyzy R, Thompson BT, Ancukiewicz M (2006) National Heart, Lung, and Blood Institute Acute Respiratory Distress Syndrome (ARDS) Clinical Trials Network Efficacy and safety of corticosteroids for persistent acute respiratory distress syndrome. N Engl J Med 354:1671-1684

18. Meduri GU, Golden E, Freire AX, Taylor E, Zaman M, Carson SJ, Gibson M, Umberger R (2007)

Methylprednisolone infusion in early severe ARDS: results of a randomized controlled trial. Chest 131(4):954-963
19. Rezk N, Ibrahim A (2013) Effects of methylprednisolone in early ARDS. Egypt J Chest Dis Tuberc 62:167-172

20. Confalonieri M, Urbino R, Potena A, Piattella M, Parigi P, Puccio G, Della PR, Giorgio C, Blasi F, Umberger R, Meduri GU (2005) Hydrocortisone infusion for severe community-acquired pneumonia: a preliminary randomized study. Am J Respir Crit Care Med 171:242-248

21. Annane D, Sébille V, Bellissant E (2006) Effect of low doses of corticosteroids in septic shock patients with or without early acute respiratory distress syndrome. Crit Care Med 34(1):22-30
22. Sabry NA, Omar EED (2011) Corticosteroids and ICU course of community acquired pneumonia in Egyptian settings. Pharmacol Pharm 2:73-81

23. Liu L, Li J, Huang YZ, Liu SQ, Yang CS, Guo FM, Qiu HB, Yang Y (2012) The effect of stress dose glucocorticoid on patients with acute respiratory distress syndrome combined with critical illness-related corticosteroid insufficiency. Zhonghua Nei Ke Za Zhi 51(8):599-603 